\title{
PATTERN OF SEXUALLY TRANSMITTED INFECTIONS IN KING GEORGE HOSPITAL, VISAKHAPATNAM
}

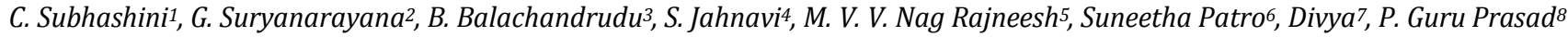

${ }_{1}^{1}$ Assistant Professor, Department of DVL, Andhra Medical College.

${ }^{2}$ Assistant Professor, Department of DVL, Andhra Medical College.

3 Professor and HOD, Department of DVL, Andhra Medical College.

4Junior Resident, Department of DVL, Andhra Medical College.

5Junior Resident, Department of DVL, Andhra Medical College.

6Junior Resident, Department of DVL, Andhra Medical College.

${ }^{7}$ Senior Resident, Department of DVL, Andhra Medical College.

${ }^{8}$ Associate Professor, Department of DVL, Andhra Medical College.

\section{ABSTRACT}

\section{BACKGROUND}

The prevalence of Sexually transmitted infections varies widely from region to region in our country. The aim of this study is to study the pattern of Sexually transmitted infections and Human immunodeficiency virus infections as seen at our Institute - King George Hospital.

\section{MATERIALS AND METHODS}

A retrospective study of patients attending Sexually Transmitted Infections Clinic, KGH, Visakhapatnam from January 2014 to December 2015 was done.

\section{RESULTS}

A total of 4,339 clients attended our Sexually Transmitted Infections Clinic, out of whom 3,117 people were suffering from sexually transmitted infections. Sexually transmitted infections were more common in females accounting for about more than 57\% (57.4\%) than males for about $42 \%$ (42.6\%). Vaginocervical discharge was the most common Sexually transmitted infection, was noted in females in our study accounting for about more than $61 \%$ (61.1\%) among all patients who are attending to our King George Hospital. Herpes genitalis was the most common ulcerative sexually transmitted genital infection noticed among the males accounting for about more than 63\% (63.50\%). Genital warts were the next most common non-ulcerative Sexually transmitted genital disease noted, which is more prevalent among males accounting for about more than $5 \%$ (71 patients, 5.3\%). Human immunodeficiency virus was found in 284 females for about 15.8\%, 201 males were infected with Human Immunodeficiency virus accounting for about $15.1 \%$ and Human immunodeficiency virus infection was noticed more commonly in patients with ulcerative Sexually transmitted infections; 233 female patients were suffering from lower abdominal pain (13\%); 18 patients were infected with inguinal bubo, 6 females and 12 males. Syphilis was diagnosed in 81 patients, among which females are 21 (11.7\%) and males are $60(9 \%)$.

\section{CONCLUSION}

Herpes genitalis was the most common ulcerative Sexually transmitted infection in males, while genital warts was the next most common non-ulcerative STI in males in our study. Vaginocervical discharge was the most common STI in females in our study.

\section{KEYWORDS}

Herpes Genitalis, Pattern, Sexually Transmitted Infections, Genital Warts, Ulcerative Sexually Transmitted Infection, Vaginocervical Discharge.

HOW TO CITE THIS ARTICLE: Subhashini C, Suryanarayana G, Balachandrudu B, et al. Pattern of sexually transmitted infections in King George Hospital, Visakhapatnam. J. Evolution Med. Dent. Sci. 2017;6(21):1659-1661, DOI: 10.14260/Jemds/2017/365

\section{BACKGROUND}

Sexually transmitted diseases or STIs are the most common notifiable infectious diseases in the world. There are serious economic and health burden more so in developing countries. The economic cost, both direct and indirect of sexually transmitted diseases is very high. Thus, sexually transmitted diseases/STIs remain a major global health concern.

Financial or Other, Competing Interest: None.

Submission 15-12-2016, Peer Review 26-02-2017,

Acceptance 04-03-2017, Published 13-03-2017.

Corresponding Author:

Dr. C. Subhashini,

Assistant Professor,

Department of DVL,

KGH, Maharanipet, Visakhapatnam-530002.

E-mail: gppatnala@yahoo.co.in

DOI: $10.14260 /$ jemds $/ 2017 / 365$ infections and delayed consequences. They are the mail precursors of preventable infertility, ectopic pregnancy, cervical malignancies and neonatal death. STIs are not only the major health problem, but also, they had a major role by enhancing HIV transmission by sexual route. Women are the most vulnerable population to sexually transmitted infections and Human immunodeficiency virus infection. The vulnerability is because they are exploited, indulged in commercial sex work or are inadvertently infected through a promiscuous spouse. The prevalence of Sexually transmitted infections varies from region to region in our Communicable Diseases Control (CDC) in its millennium development goals has identified that preventing mother-to-child transmission of HIV, AIDS and congenital syphilis is one of the five winnable battles by adopting sustained coordinated effort. Every case of infectious syphilis should be considered as a 
potential source of infection. Prostitutes and promiscuous persons form a reservoir of syphilis. The factors that operate and interact in acquisition and spread of the disease are lack of treatment facilities, ignorance about the disease, sexual promiscuity, population explosion, migration from rural to urban areas, especially young men seeking work, disproportionate male-to-female ratio in the floating population in urban and pilgrim centres, mushrooming growth of slums in cities, low moral standards, all accounting for the spread of disease. The social stigma attached to a sexually transmitted disease leads to its concealment and aids its spread. Extramarital sexual activity, disharmony with spouse, premarital sex, multiple sex partners, non-usage of condoms are the major risk factors. A systematic, regional periodic synopsis of prevalence of Sexually transmitted infections not only help to study changing trends of Sexually transmitted infections, but also to assess effectiveness of control programs. WHO estimated that approximately 340 million new cases occur every year, nearly $80 \%$ of which in developing countries.(1) Interest in sexually transmitted infections and their management increased tremendously because of proven role in facilitation of Human immunodeficiency infection.(2) Most of Sexually transmitted infections, both ulcerative and non-ulcerative are prevalent in India and constitute one of major health problem.(3) In industrialised world diseases due to chlamydia, Human papilloma virus, Human immunodeficiency virus, Herpes simplex virus are more important than classical bacterial infections. Both groups remain major health problem in most developing countries.(4)

\section{MATERIALS AND METHODS}

A retrospective analysis of clients attending Sexually Transmitted Infection Clinic, KGH, Visakhapatnam from January 2014 to December 2015 was done. Diagnosis was based on clinical history, relevant lab investigations related to HIV, HbsAg testing and VDRL tests were done in all patients after taking due consent.

\section{RESULTS}

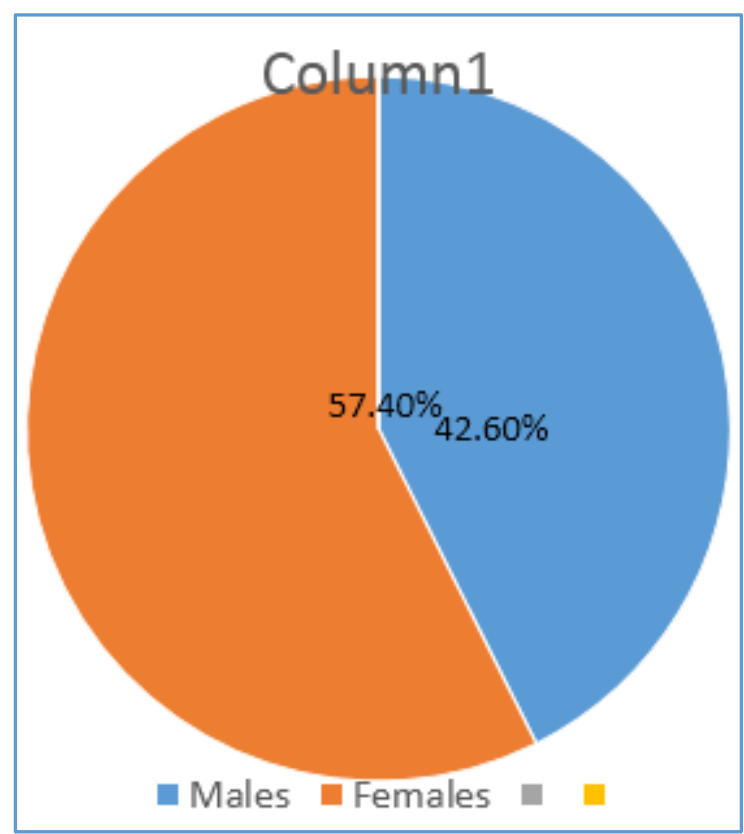

Patients attending to King George Hospital and Sexually Transmitted Clinic were diagnosed to have sexually transmitted infection more in females than males.

\begin{tabular}{|c|c|}
\hline HIV & 284 \\
\hline Vaginocervical discharge & 1092 \\
\hline Genitoulcerative disease (non-Herpetic) & 6 \\
\hline Genitoulcerative disease (Herpetic) & 105 \\
\hline Lower abdominal pain & 233 \\
\hline Inguinal bubo & 6 \\
\hline Warts & 42 \\
\hline Syphilis & 21 \\
\hline Table 1. STIs in Females
\end{tabular}

\begin{tabular}{|c|c|}
\hline HIV & 201 \\
\hline Genitoulcerative disease (non-Herpetic) & 39 \\
\hline Genitoulcerative disease (Herpetic) & 845 \\
\hline Urethral discharge & 100 \\
\hline Inguinal bubo & 12 \\
\hline Warts & 71 \\
\hline Syphilis & 60 \\
\hline Table 2. STIs in Males
\end{tabular}

\section{DISCUSSION}

Sexually transmitted diseases are the most common notifiable infectious diseases in the world. They are serious economic and health burden, more so in developing countries. The economic cost, both direct and indirect of STDs is high. Added to this is the cost of tertiary care for the complications of STDs/STIs. There was a reduction in the incidence of STDs till immediately after the II World War. Since 1955, there has been a persistent rise in the incidence of STDs. The reasons were thought to be due to promiscuity, increased movement of population, migration of workers and lesser social norms. The annual rates of gonorrhoea were very high in South East Asian, Eastern Mediterranean and Western Pacific areas. WHO in 1962 recognised this fact and concluded that antibiotics alone will not be able to contain gonorrhoea and that it has to be recognised as a public health problem. In Indian scenario, the exact burden of STI remains relatively unknown. This is due to lack of a comprehensive surveillance system, which in turn is due to the cost involved and capacity of community based surveys. A community based survey by ICMR in $2002-03$ showed that $5-6 \%$ of sexually active adult population suffer from STIs. Though the incidence is high, there is a low level of awareness of STIs and treatment seeking behaviour. In India, there is marked heterogeneity in the epidemiology of STIs.(5) STDs and HIV are the main causes of healthy lifestyle in men in the age group of 15 - 40 years, almost ranging to $15 \%$.(6) The rate of STIs in rural and urban areas is the same.(5) This brings the question as to whether the factors leading to STI are the same in both areas. It is estimated that annually approximately 30 million episodes of STI occur in India. Women are more vulnerable population to STI. This is because they are exploited, indulge in commercial sex work inadvertently infected through promiscuous spouse. In our study, nearly more than half of our study population were diagnosed to have STI. There is a gradual trend towards an increase in female attendees in STI Clinic, as evident in previous studies by Kumar B et al and Murugesh SB et al.(7,8) Most of STI cases 
belonged to 21 - 30 years' age group, which is sexually active group and at high risk of being behaviourally more vulnerable to STI acquisition, as they generally have higher number of sexual partners and more concurrent partnerships and changing of partners more often than older age group. ${ }^{(9)}$ This is also predominant age group suffering from STI as evident in study by Bairy I et al and Narayanan B et al.(10,11) Syphilis was the second most common ulcerative STID, its incidence decreased when compared to previous years. ${ }^{(12,13)}$ Chancroid seems to be on decline as evident from studies by Garg BR et al, Thappa et al and Parmar J et al.(12,13,14) O'Farrel(15) showed that while GUD attributable to HSV 2 was increasing, that caused by bacteria was decreasing. Viral STIs not only have high infectivity, but also tend to be reactivated frequently in persons with immunocompromised state. HSV infection is common in patients with AIDS with prevalence of 18 - 27\%.(16) Our study showed higher incidence of gonococcal urethritis than nongonococcal compared with Kumar B et al and Chaudary SD et al. $(7,15)$ Prevalence of HIV among STI clients in India has been on rise.(14) Proportion of female clients is increasing.(17) HIV seropositivity was more commonly seen with ulcerative STIs, especially herpes genitalis consistent with study by Thappa DM et al.(13)

\section{CONCLUSION}

Increasing health education about transmission of HIV and need to test, brought more individuals for voluntary screening.

\section{REFERENCES}

[1] WHO/HIV-AIDS/2001-02. World Health Organization. Global prevalence and incidence of selected curable sexually transmitted infection: overviews and estimates. Geneva 2001.

[2] Wasserheit JN. Epidemiological synergy: interrelationship between human immunodeficiency virus infection and other sexually transmitted disesases. Sex Transm Dis 1992;19(2):61-77.

[3] Ray K, Bala M, Gupta SM, et al. Changing trends in sexually transmitted infections at a regional STD center in north India. Indian $\mathrm{J}$ Med Res 2006;124(5):559-68.

[4] De Schryver A, Meheus A. Epidemiology of sexually transmitted diseases: the global picture. Bull World Health Organ 1990;68(5):639-54.
[5] www.cdc.gov/std/stats10/tables/htm accessed on Mar 17, 2012.

[6] National STI/RTI control and prevention program NACP III NACO 2012.

[7] Kumar B, Handa S, Malhotra S. Changing trend in sexually transmitted diseases in Chandigarh. Ind J Sex Transm Dis 1995;16:24-7.

[8] Murugesh SB, Sugareddy, Raghunath S. Pattern of sexually transmitted disease at Davengere. Indian J Sex Transm Dis 2004;25(1):10-2.

[9] Wellings K, Nanchahal K, Macdowall W, et al. Sexual behaviour in Britain: early heterosexual experience. Lancet 2001;358(9296):1843-50.

[10] Bairy I, Balachandran C, Shivananda PG. HIV seropositivity in STD clinic attendants. Ind J Sex Transm Dis 2001;22(1):6-9.

[11] Narayanan B. A retrospective study of the pattern of sexually transmitted diseases during a ten year period. Indian J Dermatol Venerol Leprol 2005;71(5):333-7.

[12] Garg BR, Baruah MC, Sait MA. Pattern of sexually transmitted diseases at JIPMER, Pondicherry. Indian J Sex Transm Dis 1985;6:41-3.

[13] Thappa DM, Singh S, Singh A. HIV infection and sexually transmitted diseases in a referral STD centre in south India. Sex Transm Infect 1999;75(3):191.

[14] Parmar J, Raval RC, Bilimoria. Clinical profile of STDs in a civil hospital, Ahmedabad. Indian J Sex Transm Dis 1988;9:4-7.

[15] O'farrell N. Increasing prevalence of genital herpes in developing countries: implications for heterosexual HIV transmission and STI control programme. Sex Transm Infect 1999;75(6):377-84.

[16] Gilmore ES, Kulwichit W. Immunocompromised patients: human immunodeficiency virus and nonhuman immunodeficiency virus positive. In: Arndt KA, Hsu JT, eds. Manual of dermatologic therapeutics. $7^{\text {th }}$ edn. Philadelphia: Lippincort Williams and Wilkins 2007:118-27.

[17] Choudhry S, Ramachandran VG, Das S, et al. Serological profile of HSV-2 in patients attending STI clinic: evaluation of diagnostic utility of HSV-2 IgM detection. Indian J Pathol Microbiol 2009;52(3):353-6. 